\title{
EVALUATION OF THE COLORANT TWINS FOR THE NEUTRAL GREY SPECTRA IN INFRARED GRAPHIC PROCEDURE
}

\author{
Ivan Pogarčić, Ana Agić, Maja Matas
}

Original scientific paper

Managing process inks in the Infrared graphics system is set through grey colour properties, based on the CMY dye synthesis. The half toning microstructure is entirely different for the colorant twins achieved in two ways, and applying inks on paper. In the visual domain colour experience is made by CMY colorants, the second within Z domain is made only with $\mathrm{K}$ ink. Screening composition of $\mathrm{V}$ and $\mathrm{Z}$ images created for marking in NIR domain is observed by microscope on the elementary screening cell level. Two ways of comparing the quality of colorant twins is used, visual and instrumental. Grey colorant twins are basis of dual reproduction, developing colorant twins for the neutral grey area and a big range of other colours, and especially for the procedure of hiding graphics in a visual part. Proposed are interdependent relations of basic grey tone colorant twins for determining CMY day compositions for process printing.

Keywords: colorant twins; grey hue screens; INFRAREDESIGN, near infra-red spectrum; Z-parameter

Razvoj blizanaca bojila za procedure u Infrared grafici u neutralnom sivom spektru

Izvorni znanstveni članak Upravljanje procesnim bojilima u sustavu Infrared grafika postavljamo kroz svojstva sive boje, bazirane na CMY sintezi. Mikrostruktura rastriranja je potpuno različita za parove blizanaca bojila izrađene na dva načina, te nanošenjem bojila na papir. U vizualnom dijelu postavlja se sistem stvaranja doživljaja boje sa CMY bojilima (V slika), a drugi sastav blizanca unutar Z područja čini samo karbon crno bojilo. Rasterski sastav V i Z slika, kreiran za obilježavanje u bliskom infracrvenom spektru, promatra se mikroskopski na razini rasterskog polja. Uspoređuju se postupci ocjene kvalitete blizanaca bojila: vizualno, te instrumentalno. Sivi blizanci su osnova dvojne reprodukcije, ali i razvoja blizanaca za tisak u neutralnom - sivom području, ali i za veliki raspon ostalih boja, a napose za postupak sakrivanja grafike u vizualnom spektru. Predložene su relacije međuzavisnosti bazičnih sivih blizanaca bojila s kojima se određuje osnovni sastav procesnih bojila C, M, Y za procesni tisak.

Ključne riječi: bliski infracrveni spektar; blizanci boja; INFRAREDESIGN; rasteri sivog tona; Z-parametar

\section{Introduction}

Grey colorant twins are defined as dyes of the same visual colour response in a visual spectrum, but with a different material composition. This is allowed by achromatic exchange of colours in the reproduction $[1,2]$ In other words, that procedure allows a huge variety of basic inks combinations, but visually they appear the same. In this paper CMY reduction is performed. Pure CMY combination has its pure $\mathrm{K}$ coverage pair. Accuracy verification of all twin colour pairs in visual (V) and Zinfrared properties is performed by spectrofotometric means covering the range from 400 to $1000 \mathrm{~nm}$. Colorimetric $L^{*} a^{*} b$ parameters including CIE $\Delta \mathrm{E}$ that describe numerical colour specification [3] and differences in visual are observed, while in NIR Zparameter is verified. Distinguishing material ink composition with reference to $\mathrm{CMY}+\mathrm{K}$ coverage is observed in visual and beyond visual in NIR. Focuses of our interest are the visual and NIR spectrum. Differences in absorption properties of inks in colorant twins are utilized with benefit of creating two different content graphics applying CMYKIR system technology. The result is one visual image, and another image "hidden" from the human eyes [4], but "visible" instrumentally with NIR Z-RGB camera for the near infrared domain, as described in [10]. IRG technology and CMYKIR separation is based on twin colour pairs, and it is possible to use them with all standard printing technologies $[5,6]$.

\section{Grey colorant twin printing and microscopic enlarged image}

This article is focused on demonstrating the differences of grey tones through three ways of colorant twins observation: screen elements microscopic observation, spectroscopic analysis and visual evaluation of a hidden Z-graphic.

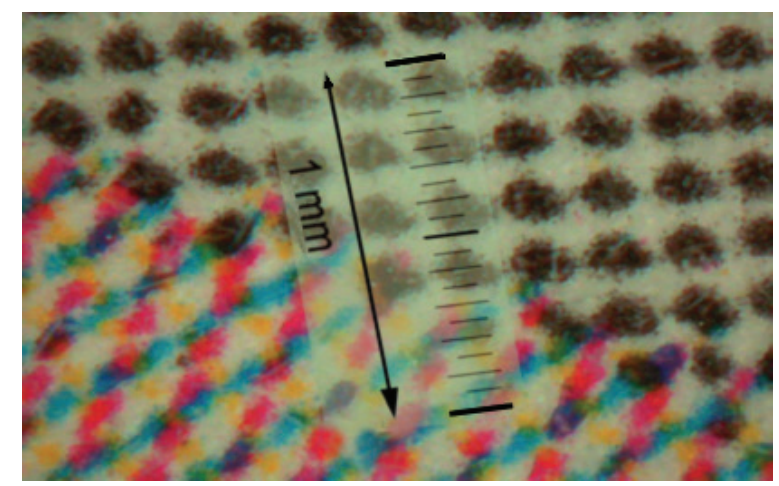

Figure 1 Enlarged detail of 60 lines halftoned area, elliptic, grey $40 \%$ coverage

The first way of verifying twins is determining ink coverage on the microscopic level, and distribution check of screening elements. This provides a colour management inspection in device's output or its software used for printing plate production, for preserving IRG technology properties in whole $\mathrm{V}$ and $\mathrm{Z}$ spectrum. Digital output devices softwares have different CMY printouts in the whole coverage range, and do not strictly carry out the programmed task. If output device-printer or CTP system do not enable the entire "zero separation", then a solution 
can be carried out by adjusting CMYKIR programming module, and creating a custom profiletor target device. Fig. 1 presents halftoned image enlarged to show differences in the coverage composition of colorant twins.

Coverage ratios of $\mathrm{V}$ and $\mathrm{Z}$ inks are adjusted for achieving the same visual effect (Figs. 1, 2a, 2b, 2c enlargement of 60 lin. ruling, elliptic). Colorant twins in this work are made with the Xeicon DCP32D digital print and electrophotographic dry toner. Created colorant twins are precisely extremely planned, and adjusted as the outmost CMY or $\mathrm{K}$ coverage combinations. Z-gray twin contains no $\mathrm{CMY}$ inks, only $\mathrm{K}$ ink, and the $\mathrm{V}$ twin is assembled only from CMY inks coverage. For such pairs, coverage composition could differ from theoretical or "standard" setting in the presented measured samples. The final decision gives a human perception, while "hiding" the Z-image.
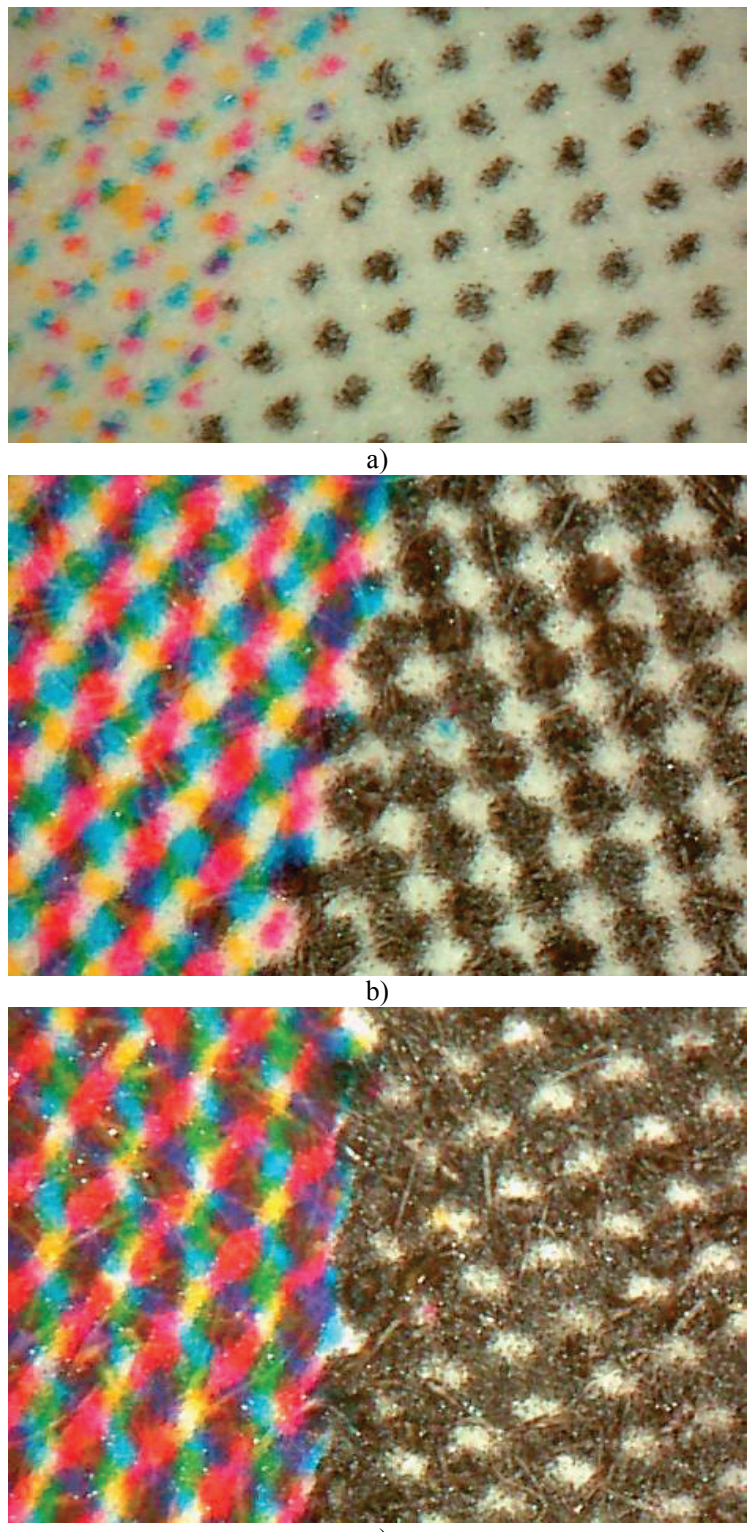

Figure 2 Microscopic images of twin pairs, 60 lines ruling, elliptic: a) grey $20 \%$ coverage; b) enlarged grey, $60 \%$ coverage; c) enlarged grey, $60 \%$ coverage

On the first glance, it is hard to accept the fact that image is layered, respectively twin pairs (Fig. 1, 2) on the left and right pair side will produce the same gray experience.

Table 1 Twin pairs coverage C, M, Y composition for $\mathrm{V}$ and $\mathrm{Z}$ state (dedicated example) achieving optimal grey balance and $\mathrm{K}$ substitution

$\begin{array}{llllll}\text { grey } 10 & \text { (CMY) } & 11 & 8 & 7 & \text { equivalent K } 10 \\ \text { grey 20 } & \text { (CMY) } & 19 & 16 & 20 & \text { equivalent K 20 } \\ \text { grey 30 (CMY) } & 29 & 23 & 18 & \text { equivalent K 30 } \\ \text { grey } 40 \text { (CMY) } & 35 & 31 & 27 & \text { equivalent K } 40 \\ \text { grey 50 (CMY) } & 44 & 39 & 31 & \text { equivalent K 50 } \\ \text { grey 60 (CMY) } & 51 & 50 & 39 & \text { equivalent K 60 } \\ \text { grey 70 (CMY) } & 65 & 57 & 54 & \text { equivalent K 70 } \\ \text { grey } 80 \text { (CMY) } & 77 & 67 & 64 & \text { equivalent K 80 }\end{array}$

When viewing halftoned fields from a normal reading distance, fields in 60 lines ruling Fig. 3, no difference can be observed. Left part of the twin pair contains CMY coverage combination printed on the substrate, while the right contains only $\mathrm{K}$ ink coverage component. These stages present extreme stages, with only CMY and only $\mathrm{K}$ component. As practically the same optical density visually is achieved, it can be treated as equivalent neutral density (END), often used in reproduction. The right part of the twin pair is easier acceptable for the interpretation, while the screening element size is larger, "greyness" is larger and the reflection decreases, as ratio of covered part and uncovered substrate defines a grey reflection. Screening elements are small enough not to be observed individually, and human perception system "integrates" this area in the ultimate cumulative perception.

Numerical values in the second line of Fig. 3 (circular graphics) are coverage of cyan, magenta and yellow. Black has a zero value. These colours are twins for a clean black (grey). The coverage values of $\mathrm{C}, \mathrm{M}$ and $\mathrm{Y}$ are equal to zero.

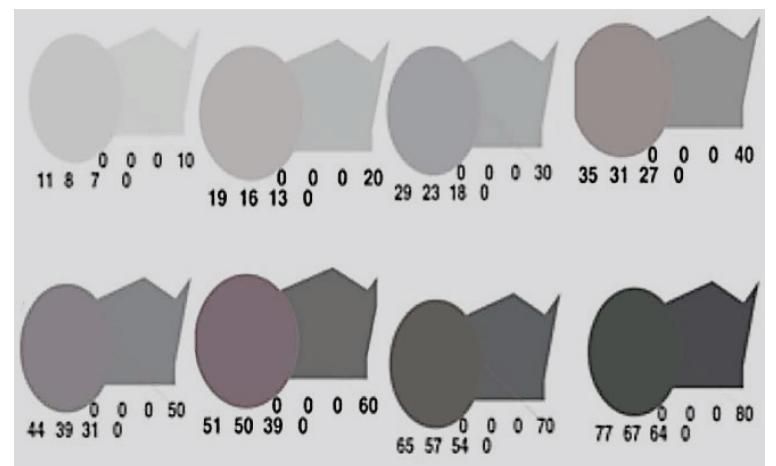

Figure 3 Series of realised twin pairs from Tab. 1 (example)

The left part of the colorant twins also preset gray perception, although they are composed of the coloured inks, $\mathrm{C}, \mathrm{M}, \mathrm{Y}$, which are different from $\mathrm{K}$ ink gray. However, these coloured inks in supposed ratio, (table 1) in subtractive synthesis manner, will produce an absorptive combination that we will experience as grey tone (level). Every hue, including greys can be colorimetrically described, e.g. such as $L^{*} a^{*} b$ coordinates. Greys have $a^{*}$ and $b^{*}$ values small, near to achromatic point. It must be mentioned that in RGB colour system greys have the same coordinates, but in the CMY reproduction depend on the output system. Grey tones in the IRG technology differ from the standard 
reproduction rules, as $\mathrm{K}$ component is directed to NIR spectrum alone, with no influence of the CMY system's components. Only this value, as the maximum response in Z-point equalizes with $\mathrm{CMY}$ ratio, and $\mathrm{K}=0$ in the visual spectrum. Real carbon black inks and toners gain small $a^{*}$ and $b^{*}$ values. RGB system values do not directly offset for the real process inks when greys are defined through $\mathrm{K}$ values. IRG while using process colours often defines $\mathrm{K}$ maximal light absorption value in Z-point, where the hidden image is measured. Such twins with utter contrast between $\mathrm{V}$ and $\mathrm{Z}$ colorants are the base of IRD procedure.

\section{Twins spectra in the visual and NIR}

The second step in the colorant twin pairs evaluation is equalizing colour (combinations) by means of twins spectrograms. Through the spectrogram means and iterative approach in reproduction with practical experiments equalizing twins of $\mathrm{V}$ and $\mathrm{Z}$ spectra is performed. Tuning of CMY components amount of inks is in V part, while in this article Z-twin is tuned only through the K-component ink. Separate absorption spectra of $\mathrm{CMY}$ and $\mathrm{K}$ inks are already discussed. There are standard graphic arts inks and colorants that are also considered in all gray hues. Final spectra in Figs. 5 and 4, and trend lines Fig. 6, described, finalize further investigations for twin pairs of described series. Twin pairs described, Fig. 4, are two grey "colours", both with $40 \% \mathrm{~K}(\mathrm{~B} 1, \mathrm{~B} 2)$ coverage, combination important for observed twins and $80 \%$ twins A1, A2. Upon $800 \mathrm{~nm}$ it is evident that twins defined in right twin pair part will respond (Fig. 4), and from 900 to higher wave lenghts is Z-domain that clearly establishes and defines the second image. These parameters are attuned very precisely for any default situation.

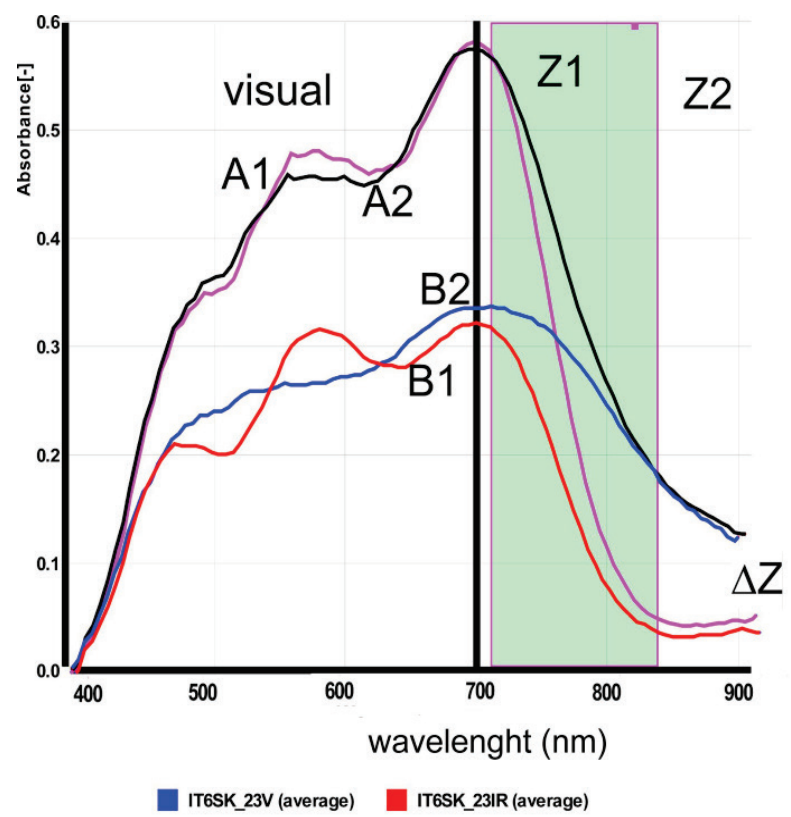

Figure 4 Absorption curves in the visual and $\mathrm{Z}$ domain for a selected gray twins. A1 and A2 are lower intensity greys 80-80-80-0; 58-55-7040 , and B1 and B2 higher intensity pair 40-40-47-0; 0-0-0-40.

Twins are observed and examined in three spectral regions: $V, Z_{1}$ and $Z_{2}$ as a part of the near infrared spectra before. $Z_{1}$ is transient domain in the near infrared, 700 to
$850 \mathrm{~nm}$, Fig. 4. This is the area of hybridism of images defined for $\mathrm{V}$ and $\mathrm{Z}$ state. In that domain separations of $\mathrm{V}$ and $\mathrm{Z}$ inks are disjoining, but are still present. CMYKIR separation is routing to $1000 \mathrm{~nm}$ domain. $Z_{2}$ defines the undisturbed separation area that will be detected by Zcamera. $Z_{2}$ ends on $1000 \mathrm{~nm}$ where $\mathrm{Z}$-parameter is established for the absorption measurement where the second-hidden image will be detected, Fig. 7.

Examination of extreme defined twins from the base of the IRG procedure ensures planned results in appliance.

\section{Final twin pairs evaluation}

The third reason of twin' efficacy is the visual experience, in other words what we see by bare eyes. A visual evaluation does not have a numerical scientific background, but it is crucial in the final twins quality decision. Principles of IRD, IRG technology are subjected to the mutual hiding of two graphics. Hiding the second graphics from our eyes is final or key quality factor of twins efficiency.

Successful acquirement of the realised twins requires fulfilling three steps:

Microscanning/magnificatioin Figs. 1 and 2, spectral analysis and colorimetric evaluation Fig. 5, and visual estimation.
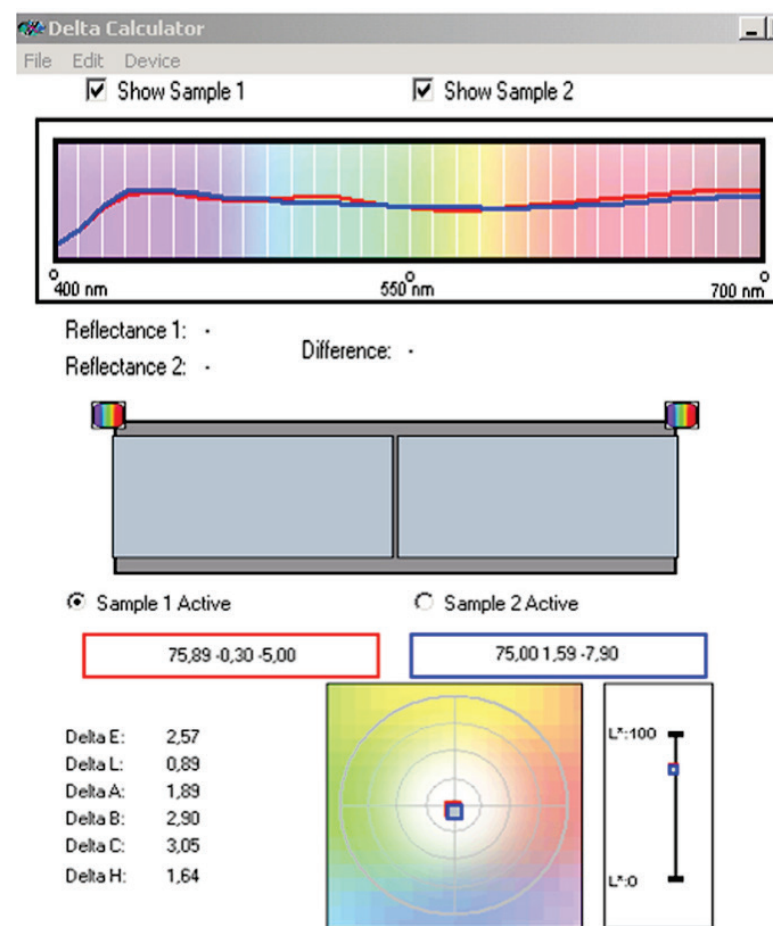

Figure 5 Spectroscopic and colorimetric analysis of a grey twins pair (example, $40 \%$ coverage)

CIE $\Delta \mathrm{E}_{76}$ values achieved in observed case for $20 \%$ coverage $1,88,60 \%$ coverage $2,69,80 \%$ coverage 2,89 .

\section{Procedure of interchanging $\mathrm{CMY}$ inks components with $\mathrm{K}$ component}

Defining and determining primary colours trendlines, which implies maintaining and some profiling properties, can be described as quadratic polynomial functions 
presented as a reduction curves, Fig. 7 and Fig. 8. It must be stated that for each reduction rate separate reduction trendiness functions and calculations have to be performed. The shape, mathematical function and (re)calculation have to be repeated.

Grey tone of the twin with $80 \%$ substituted black ink expresses very good match in the whole visual spectrum. Cyan ink is a replacement in the area 400 and $650 \mathrm{~nm}$ for process $\mathrm{M}$ and $\mathrm{Y}$ inks that are weak areas. Lighter grey tone with $40 \%$ black ink that attempts to equalize with CMY components is not useful in achieving a quality grey. At $550 \mathrm{~nm}$ there is a strong transition influence from yellow to magenta. There is a compromise between yellow and magenta amounts. Graph of black ink B1 intersects graph B2 that represents only CMY combination. In that spectrum part, there are not enough cyan components that mostly effect smoothing of visual spectrum on lower wave lengths. Cyan ink is the most liable for approaching $\mathrm{C}$ M Y to carbon $\mathrm{K}$ ink. Yellow ink is the least sensible on IRD procedure in method of interchanging CMY with K. Final decision on the mutual relations of CMYK is left to our bare eyes and materials where Infraredesign technology appliances of hiding graphics procedure.

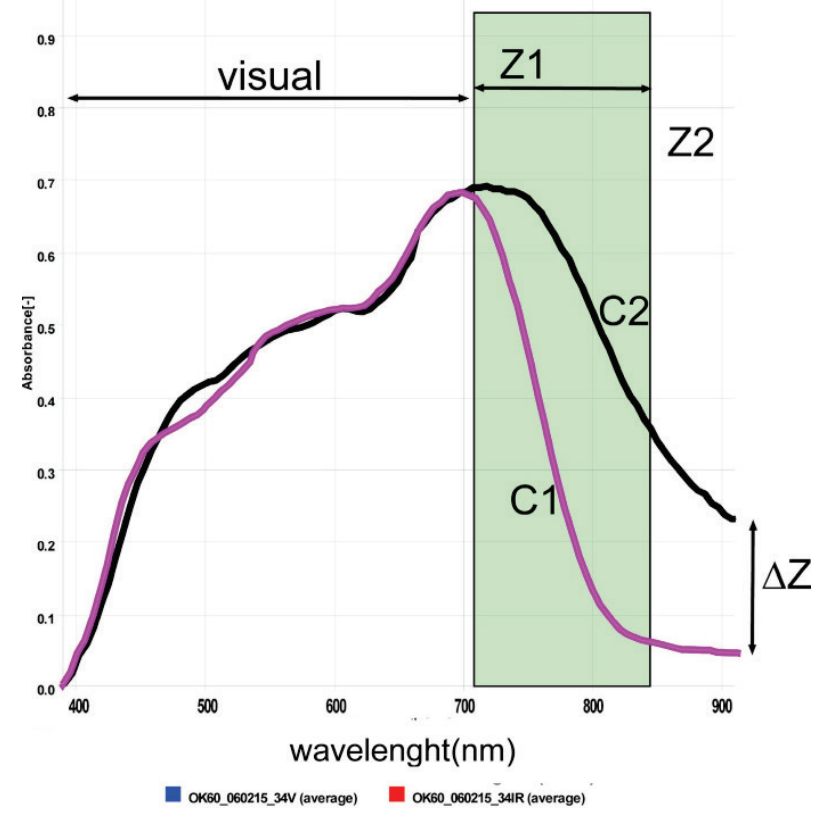

Figure 6 Absorption curves of $60 \%$ black ink (C1) and corresponding CMY combination $(\mathrm{C} 2)$

Fig. 6 presents an absorption spectrum of a twin with $60 \%$ carbon black pigment component. That twin has larger $\Delta \mathrm{E}$ difference than $40 \%$ carbon black twin. Relation values of $\mathrm{K}_{60}$ are for $\mathrm{Z}$ twin: $\mathrm{C}=3 \%, \mathrm{M}=8 \%$, $\mathrm{Y}=14 \%, \mathrm{~K}=60 \%$. Process printing inks values for both $\mathrm{V}$ twins: $\mathrm{C}=50 \%, \mathrm{M}=50 \%, \mathrm{Y}=50 \%$ and $\mathrm{K}=0$ $\%$. In the visual part evenness is high, and a rather large difference in $Z$-point is achieved, in $Z_{2}$ area.

Procedure of achieving $\mathrm{V}$ and $\mathrm{Z}$ twins is based on IRG method of mutually hiding two graphics. Spectrogramme equivalence in the visual provides that two graphics cannot be distinguished. Recognition and identification of two graphics is possible only in the infrared spectrum. Graph, Fig. 5, illustrates absorptions differences in the end of $Z_{2}$ domain. This difference denoted as $\Delta \mathrm{Z}$ can be visualised with infrared camera as a strong contrast that identifies two graphics, two pictures.

Such graphical and mathematic-analytical approach could be used for observing, manipulating and adjusting each hue or tone, but also for every set of twin pairs, while this is notable part of profiling procedure, important for CMYKIR procedure, already published.

These grey twin pairs are obtained through modelling procedures and derived linear regression for Xeicon DCP32/HarlequinRIP dry toner digital printing machine. Mathematical relations for offset differ respectively they should be adjusted for each output system. Presented are example regression procedures, for 40 and 60 interchange trendlines, procedure described in $[8,9]$.

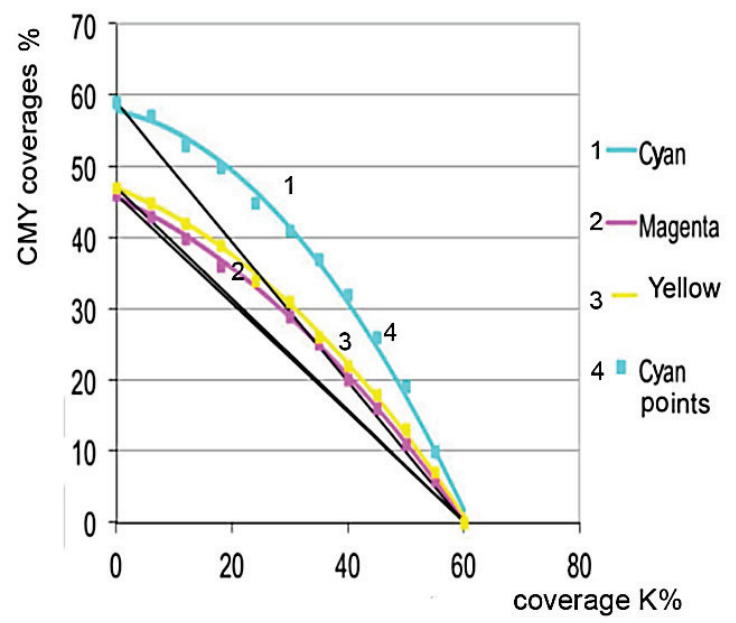

Figure 7 K-60 interchange trendlines, CMY coverage K \%

$$
\left|\begin{array}{c}
C \\
M \\
Y
\end{array}\right|=\left|\begin{array}{ccc}
-0,01289 & -0,16056 & 57,91 \\
-0,0065 & -0,36741 & 45,62 \\
-0,0075 & -0,32187 & 46,97
\end{array}\right| *\left[\begin{array}{c}
K^{2} \\
K \\
1
\end{array}\right]
$$

Transformation colours to K-60 matrix

$$
\left|\begin{array}{c}
C \\
M \\
Y
\end{array}\right|=\underset{\begin{array}{ccc}
-0,01184 & -0,47723 & 38,55 \\
-0,00406 & -0,47048 & 25,68 \\
-0,0051 & -0,48932 & 27,92
\end{array} \mid}{\text { Transformation colours to K-40 matrix }}\left[\begin{array}{c}
K^{2} \\
K \\
1
\end{array}\right]
$$

Corresponding (re)calculations were made for all observed points (coverages).

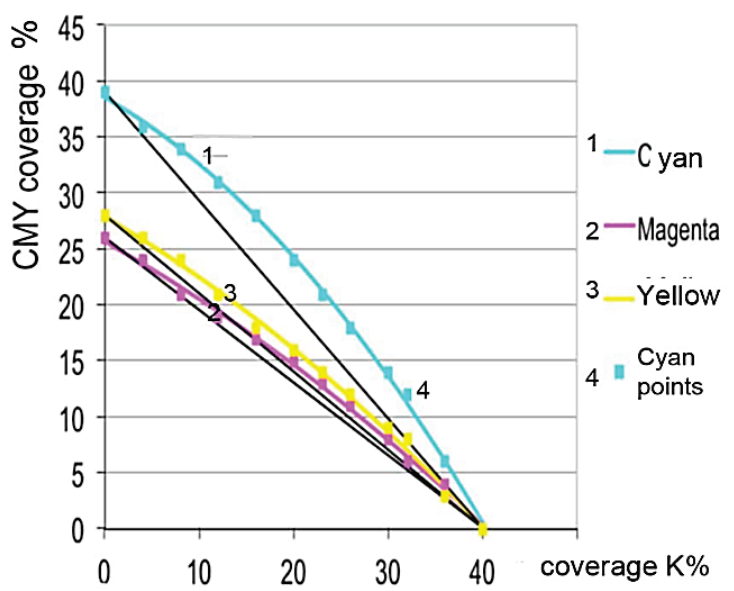

Figure 8 K-40 interchange trendlines, CMY coverage K \% 


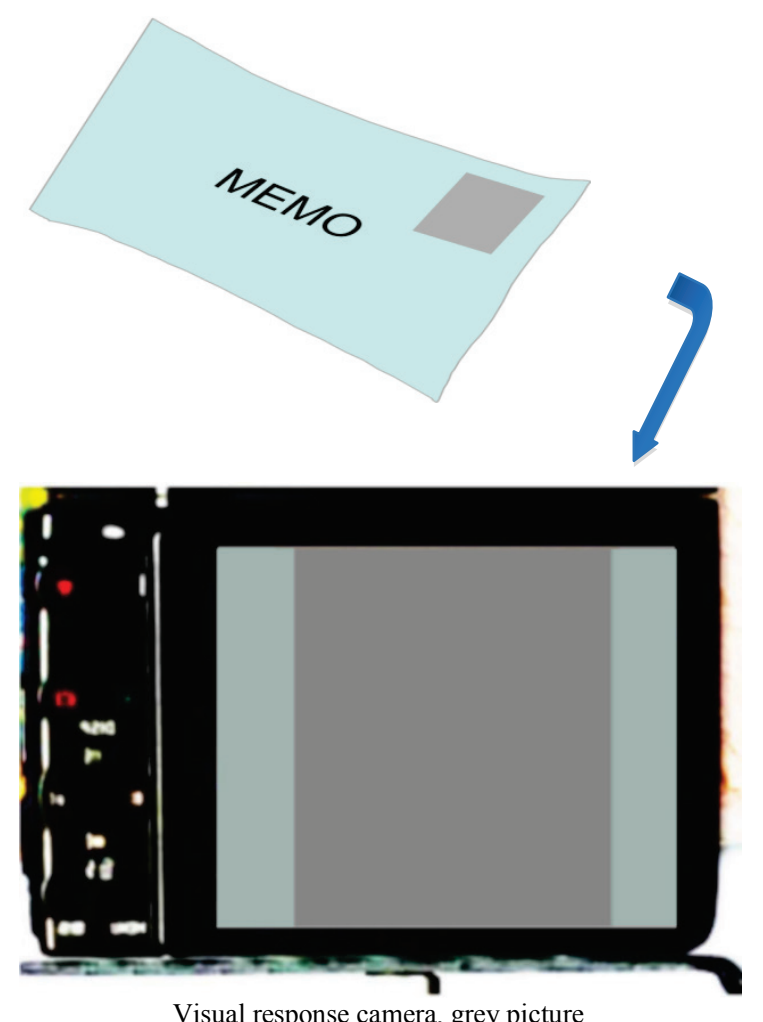

Visual response camera, grey picture

a)

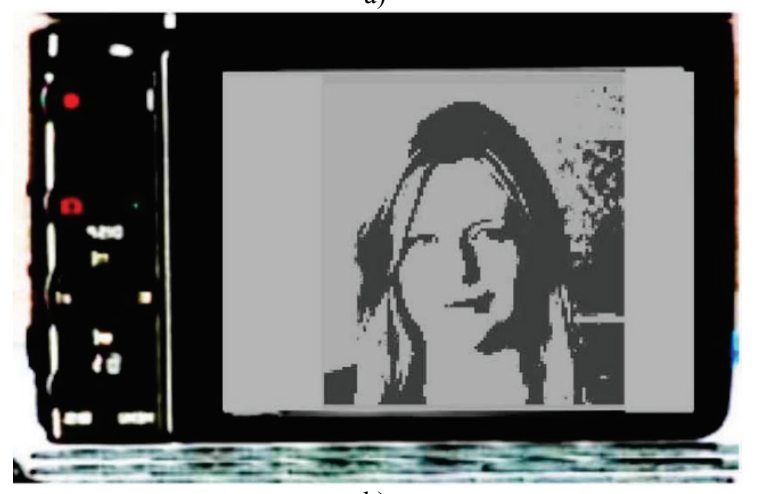

b)

Figure 7 a) Part of a document exposed with camera for visual (V), and secondary image with $Z$ camera; b) NIR image response ( $Z$ camera image)

Two cameras from ZRGB systems show different information that is part of the IRG reproduction. Portrait is published for only $\mathrm{Z}$ camera, hidden in a grey IRG print. This reproduction is performed with CMYKIR separation with $40 \%$ greyness, meaning $40 \%$ grey reduction. The camera gives a great contrast to what is achieved in the menu of the camera. Planned graphical printing prepress for $\mathrm{Z}$ image is limited to the greyness of less than $50 \%$ in order to spread spectrum utilization of other process CMY inks. For larger values of the default input $\mathrm{Z}$ pictures, reproduction would be too gray. The desire for more saturated colours on the printout is subordinated to compromise setup options $\mathrm{Z}$ cameras and limitations of CMYKIR separation. Therefore, the analysis of grey tones twins colour is directed towards achieving a greater efficiency of IRG system hiding and recognition of the infrared image.

\section{Conclusion}

A high quality twin pairs of inks are achieved according to IRG theory for target reproduction system, checked according to instrumental and optical criteria. Construction of the basic reproduction curve implies correct gray balance, in this case distinguishing $\mathrm{M}$ and $\mathrm{Y}$ reproduction curve, dedicated for output unit with defined screening system (60 lin, elliptic), what was basic for achieving observed twin patches. It is hard to believe that the left and right parts of the image present practically the same neutral tone visual output, according to Figs. 1, 2 and 3. Their spectrograms are practically the same in 400 $\div 700 \mathrm{~nm}$ domain while CIE $\Delta \mathrm{E}_{76}$ criteria is lower than 3 , although basic trendlines are calculated separately for each observed $\mathrm{CMY} / \mathrm{K}$ response. Visual evaluation is unavoidable, while some visual descriptions should be improved [7]. Such system ensures double reproduction as well as hiding of secondary graphic (image), and their appearance in Z-domain. However, that situation is the IRG base that points out new design exploring. Wide implementation is presented in different fields of technologies, technical and designer's efficiency, technology of double imaging in packaging, military uniforms, valuables, and series of different products, as solutions adopted in infrared art, infrared design, infrared textile, infrared code, infrared reproduction technologies. Grey tones are primal focus of interest while they as essential for achieving other tones and hues. When evidence about equalizing greys in visual is performed, examinations of other tones and hues can be carried out for the IRG method of mutual hiding of two pictures.

\section{References}

[1] Enoksson, E.; Bjurstedt, A. Compensation by black - a new separation? // TAGA 2006, Vancouver, Canada, TAGA Proceedings 2006, pp. 193-217.

[2] Agić, D.; Rudolf, M.; Agić, A.; Stanić-Loknar, N. Case Study: Carbon Black Separation Extended Features // Proceedings - The Sixth International Symposium GRID 2012 / Novaković, D. (ed.). Novi Sad: Faculty of Technical Science, Department of Graphic Engineering and Design, 2012, Pp. 187-194

[3] Fraser, B. Real World Color Management, Peachpit Press, Barkeley CA, ISBN 0-3231-26722-2, 2004.

[4] Friščić, M.; Medjugorac, O.; Tepeš, L.; Jurečić, D. Invisible Information on the Transparent Polymer Food Packing with Infra V/Z Technology. // TTEM. 8, 4(2013), pp. 15121519.

[5] Hunt, R. W. G. The Reproduction of Color, John Willey and Sons, 2004, ISBN 0- 470-02425-9.

[6] Kipphan, H. Handbook of Print Media, Technologies and Production Methods, Sec. 3: Prepress, Springer Verlag Berlin, New York, 2004, ISBN 3-540-67326, pp. 474-487, 2004.

[7] Choudhry, A. K. R. Visual measures of colour // Principles of Colour and Appearance Measurement. Volume 2: Visual Measurement of Colour, Colour Comparison and Management. 2015, pp. 1-25. DOI: 10.1533/9781782423881.1

[8] Žiljak, I.; Pap, K.; Žiljak, V. Double Separation Method for Translation of the Infrared Information into a Visible Area. // Journal of Information and Organizational Sciences. 33, 1(2009), pp. 219-225.

[9] Žiljak Vujić, J.; Agić, A.; Stanić Loknar, N. Picture information in expanded color management from visual to 
near infrared spectral domain. // Technics Technologies Education Management. 8, 3(2013), pp. 942-950.

[10] Ziljak, V.; Pap, K.; Ziljak-Stanimirovic, I. Development of a prototype for ZRGB INFRAREDESIGN device. // Tehnički vjesnik. 18, 2(2011), pp. 153-160.

\section{Authors' addresses}

doc. dr. sc. Ivan Pogarčić

Corresponding author

Veleučilište u Rijeci,

Vukovarska 58, 51000 Rijeka, Croatia

E-mail: pogarcic@veleri.hr

Ana Agić, mag. ing. techn. graph. Grafički fakultet,

Getaldićeva 2, 10000 Zagreb, Croatia

E-mail: ana.agic@grf.hr

Maja Matas, mag. ing. techn. graph. Grafički fakultet,

Getaldićeva 2, 10000 Zagreb, Croatia

E-mail: maja.matas@grf.hr 